\title{
SoSTeM Model Development for Application of Soft Skills to Engineering Students at Malaysian Polytechnics
}

\author{
Ahmad Esa ${ }^{1}$, Suhaili Padil ${ }^{1}$, Asri Selamat ${ }^{1} \&$ Mohammad Talha Mohamed Idris $^{2}$ \\ ${ }^{1}$ Faculty of Technical \& Vocational Education, Universiti Tun Hussein Onn Malaysia, Batu Pahat, Johore, \\ Malaysia \\ ${ }^{2}$ Faculty of Science, Technology \& Human Development, Universiti Tun Hussein Onn Malaysia, Batu Pahat, \\ Johore, Malaysia \\ Correspondence: Ahmad Esa, Faculty of Technical \& Vocational Education, Universiti Tun Hussein Onn \\ Malaysia, 86400 Batu Pahat, Johore, Malaysia. Tel: 607-453-7480. E-mail: ahmad@uthm.edu.my
}

Received: May 7, 2015 Accepted: June 9, 2015 Online Published: October 28, 2015

doi:10.5539/ies.v8n11p204 URL: http://dx.doi.org/10.5539/ies.v8n11p204

\begin{abstract}
Soft skills are some of the skills needed to ensure that graduates fulfill the needs of the job market. Until 2010 , almost 30\% of unemployed graduates in Malaysia are technical graduates and one third comes are graduates from polytechnic. Most engineering graduates are proficient in technical skills but lack in soft skills. The lack of relevant knowledge among lecturers in order to identify appropriate ways and methods in the process of teaching and learning is one of the causes of lack in soft skills application. This study aims to identify the suitable teaching methods for the application of soft skills in the engineering programs for engineering students in Malaysian polytechnics. 488 students and 332 lecturers in engineering courses at the polytechnic had been questioned using questionnaires and interviews. The results showed that there is a relationship between the level of application of soft skills element with the teaching \& learning methods used by lecturers. Based on these relationships, researchers had produced $\operatorname{SoSTeM}$ model as the model of application of soft skills for engineering students. Researchers also discovered that the use of teaching \& learning methods for applying soft skills in engineering programs vary according to the elements of soft skills.
\end{abstract}

Keywords: soft skills, methods of teaching \& learning, engineering, polytechnic

\section{Introduction}

Soft skills are issues that are often debated in reducing the problem of unemployment and to producing knowledgeable workforce as well as highly skilled workers, especially in developing countries (Mclntosh, 2008; Hamzah, Bakar, \& Kazilan, 2006). The most obvious weakness can be detected when graduates are not able to keep pace with the rapid technological and industry requirements (Wye \& Lim, 2009; Mclntosh, 2008). Engineering's graduates skilled in technical, science, mathematics and physics, but lack control in soft skills required in accordance with the requirements of the industry (Wye \& Lim, 2009). Among initiative that can be taken to improve the skills of graduates by industry requirements is to provide facilities for vocational training, entrepreneurial training program, as well as soft skills training program to improve the relationship between industry and educational institutions (Kapsos, 2013).

In fulfilling its goal to produce students who are knowledgeable and skilled, engineering programs for the university curriculum should be designed with the goal of helping lecturers in providing guidance to the students to prepare the aspects of intellectual, spiritual, emotional and physical. Soft skills involving critical thinking and creative skills, effective communication skills, making choices and decision-making, leadership and management skills need to be taken into account when designing the content of curriculum in engineering programs and strategies of teaching \& learning (Mohd-Amin \& Mohd-Nor, 2010). Emphasis and effort in applying soft skills in teaching \& learning should be stressed out by educational institutions to produce graduates who are not only successful in academics, but also able to master other skills required as well. According to Pineteh (2012), lecturers shall act creatively integrating traditional methods of teaching and learning with technology advances so that the process of teaching and learning will not be bored thus help in improving students' communication skills. 
The use of methods that are appropriate in teaching \& learning not only help the teaching \& learning process, but also contribute in improving soft skills among students. According to the Ministry of Higher Education (2006), the development of soft skills requires skill in using a variety of methods in particular student-centered learning approach. It is also supported by Mohd-Amin and Mohd-Nor (2010) and Morris (2009) which stated that lecturers should be more creative in devising strategies in teaching \& learning so that soft skills applied to the students be more organized and appropriate. A quality of curriculum and lecturers influence the level of student skills and traits in terms of listening, responding, questioning and formulating (Morris, 2009). Therefore lecturer plays a very important role in implementing all the soft skills that are appropriate to the courses taught.

\section{Teaching \& Learning Methods for Soft Skills}

The infusion of soft skills in the curriculum of engineering program coincides with the third and fourth core of the transformation polytechnic roadmap to empower citizens with knowledge and skills as well as build a reputable image and excellent work culture (Department of Polytechnic, 2011). Che-Ani, Tawil, Johar, Ismail, and Abd-Razak (2014) and Koprowska (2006) stated that public and private institutions should work and cooperate to achieve national development goals which include the knowledge and skills to meet the demands of the skills that have reached into global levels.

Lecturers are individuals who are instrumental in implementing elements of soft skills among students at university. Curtis (2004) suggested that lecturers play important roles in diversifying teaching \& learning methods to be more open-minded when applying soft skills in technical and vocational courses. It is supported by Mok (2004), which stated the effectiveness application of soft skills in the process of teaching and learning depended on the lecturers' mastery in integrating soft skills with other skills such as thinking skills, learning skills, skills in evaluating and assessing teaching process. Centers for Excellence in Teaching and Learning Module (CETLs) have been used in the United Kingdom to encourage students to learn through experience and collaborative relationships with lecturers in improving soft skills to students (Neary \& Winn, 2009). Redoli, Sompo, Mata, and Doctor (2011) in their study suggested the use of Delphi Learning Package (DLP) tool as an approach model in applying the soft skills among engineering students during the teaching \& learning process.

In Malaysia, soft skills are emphasized by the Ministry of Higher Education Malaysia (MOHE) since 2006 through 'Soft Skills Development Module for Malaysia Higher Education Institutions' to guide higher education institutions in designing programs to improve soft skills. According to Ahmad-Anuar and Esa (2010) in a study on the application of soft skills in Pusat Giat Mara (PGM), soft skills can be learned and developed in the individual through the application methods in technical and vocational education institutions. The study found that the application of soft skills can be channeled through workshops and classes with regard to the five elements of soft skills including communication skills, leadership skills, decision making skills, problem solving skills and teamwork skills. This is consistent with studies by Knight and Elliot (2008) which stated that lecturers becomes a catalyst in encouraging students to engage in the activities carried out in class or workshop.

Diversity of teaching methods in the teaching process can assist in improving the master of soft skills among students and lecturers (see Appendix A). There are varieties of methods and approaches that can be used in applying the elements of soft skills in the process of teaching and learning in engineering programs at the university (Pineteh, 2012; Ormrod, 2006; Eggen \& Kauchak, 2001). Lecturers need to try and act creatively to translate elements of soft skills in lesson plan to enhance students' understanding through the process of teaching and learning without focusing too much on the school curriculum designed (Pineteh, 2012; Alexander, 2008; Zainal-Abidin, 2004; Hashim, Yaakub, \& Ahmad , 2003).

However, there is confusion and insufficient information among lecturers in identifying appropriate ways and means to implement the elements of soft skills in the process of teaching and learning which hindered for the lack of soft skills applied to elements in the curriculum program in universities. This is explained by Abu, Kamsah, and Razzaly (2008) which stated that the problems faced by lecturers in applying soft skills in the process of teaching and learning is due to lack of knowledge and skills to adapt and assess soft skills in the teaching \& learning process, time constraints and lack of materials and reference documents that can help them carry out teaching \& learning activities. Buntat, Saud, and Hussain (2008) noted some of the problems in the application of soft skills in the teaching \& learning were the lack of tools and equipment for practical work that prevented teachers from applying teamwork skills in the workshop. It is also supported by Zepke and Leach (2010) in their study which stated that lecturers and students agreed with the importance of soft skills, but there is issue in applying the skills in the classroom.

Based on the existed issue, a study on the use of teaching \& learning method for improving soft skills among students at the polytechnic engineering programs has been undertaken to address the shortcomings and confusion 
in promoting the application of soft skills by students.

\section{Objectives}

a) Study the relationship between teaching \& learning methods used by lecturers with the elements of soft skills possessed by students.

b) Develop a model for teaching soft skills during teaching \& learning process.

\section{Method}

This study used a descriptive survey method which aimed to engage 488 engineering students and 322 lecturers of engineering courses from six selected polytechnics. The participants were selected randomly from polytechnics representing north, central, south, east and east coast Malaysia. The study involves seven elements of soft skills: communication skills, teamwork skills, problem solving skills, leadership skills, life-long learning and information management, entrepreneurship skills and professional and moral ethics. These skills are reviewed together with the current needs of graduates in enhancing their employability as stated in the graduates' tracer study 2011. Data from the questionnaires were analyzed by inferential statistics using SPSS 20.0. Interviews were conducted and analyzed manually as secondary data to support the questionnaires. By using Delphi Learning Package (DLP) tool, a model in applying soft skills among engineering students were developed at the end of this research.

\section{Results and Discussion}

\subsection{The Relationship between Teaching \& Learning Methods and Soft Skills}

To determine the relationship between teaching \& learning method used by lecturers with elements of soft skills possessed by students, Pearson correlation test was used. There is null hypothesis,

$\mathrm{H}$ : There is no relationship between the level of application of soft skills among students and teaching \& learning methods used in the polytechnics.

Table 1. Pearson correlation test between the teaching \& learning methods used and level of soft skills

\begin{tabular}{lcc}
\hline & Soft skills & Teaching \& learning method \\
\hline Soft skills & 1.000 & 0.049 \\
Teaching \& learning methods & 0.049 & 1.000 \\
\hline
\end{tabular}

Table 1 shows the data analysis for the relationship between methods of teaching \& learning with soft skills. Pearson correlation test results conducted for respondents show the results of the test is 0.049 . Then the null hypothesis is rejected, there is a relationship between the level of application of soft skills among students and teaching \& learning methods used in polytechnics. The analysis of interview transcripts found that lecturers used various methods to encourage the application of soft skills among students.

"for me, the method is very effective... practical... because... we can understand what we do actually... compare to the lecture method... we just learn theory"

(Respondent III)

"more or less ... erm... we apply 50\% in class, for example we give arr ... a task. They got information from outside ... or at least in the polytechnic ... for example through the department ... through LI unit, counseling unit. Ok. So the application in terms of communication $50 \% \quad \ldots$ erm... during industry practice"

(Respondents VI)

"now more lecturers used outcome based education... when the outcome based education rather... erm... arr... not only one party... meaning two way communication. So if two way communications, many students... many lecturers use these techniques in outcome based education. For example... erm... presentation then peer assessment, discussion... video conference... erm... which has live... erm... real live communication... for example... if a student ... applies what the lecturer may ask... erm... in terms of their learning... he not only listen, they do also interact in class... erm ... such as doing something to better understand... mind mapping... in their class in the form of group and that they do brain storming, for mind mapping, presentation... like that..." 
Finding shows majority of respondents agreed that teaching \& learning methods used by lecturers during the process of teaching and learning was effective in encouraging students to apply soft skills in facing the working environment. However, the study found a significant relationship is weak and this is evident when the level of application of soft skills among students was still at low level even though lecturers used various methods of teaching \& learning. Variations are required in the use of teaching \& learning conducted by lecturers as described by Curtis (2004), lecturers need to be more open minded in diversifying the methods of teaching \& learning when applying soft skills in technical and vocational courses. The findings also support the view issued by Mok (2004) which stated that the effective application of soft skills in the process of teaching and learning rely on the control of lecturers integration of soft skills with other skills such as thinking skills, learning skills, skills in evaluating and assessing teaching.

Respondents also indicated the effectiveness of the application of soft skills among students depended on the seriousness of students and the expertise of lecturers during the process of teaching and learning carried out as described by Nachiappan, Kamaruddin, Abd-Shukor, Jantan, Mustapha, and Hamzah (2009) that process of teaching and learning affects the application of soft skills among students. This data supports the view by Hashim et al. (2003), which stated that in cooperative learning, methods used can help in improving interpersonal skills among students. Through cooperative learning, students do not only need to complete the tasks assigned by the teacher, but also serves as a member of the group who leads, make decisions and deal with conflict. Based on the findings, there are several other factors that should be taken into account in increasing the level of soft skills among students apart from focusing on teaching \& learning methods.

\subsection{Application of Soft Skills Model for the Engineering Program}

Based on the analysis of the first research question, researchers have developed a model of soft skills that can be applied during the process of teaching and learning for the engineering programs at the polytechnic. This soft skills model is produced based on the process of DLPT to suit the needs of engineering students as used by Redoli et al. (2011). By using SPSS, the reability value of this model is high with Alpha Cronbach value of 0.819 $(\alpha>0.7)$. Although seven elements of soft skills were studied, the results showed that only two soft skills can be applied effectively by lecturers in their teaching style. Figure 1 shows an application model of soft skills for the engineering programs at the polytechnic.

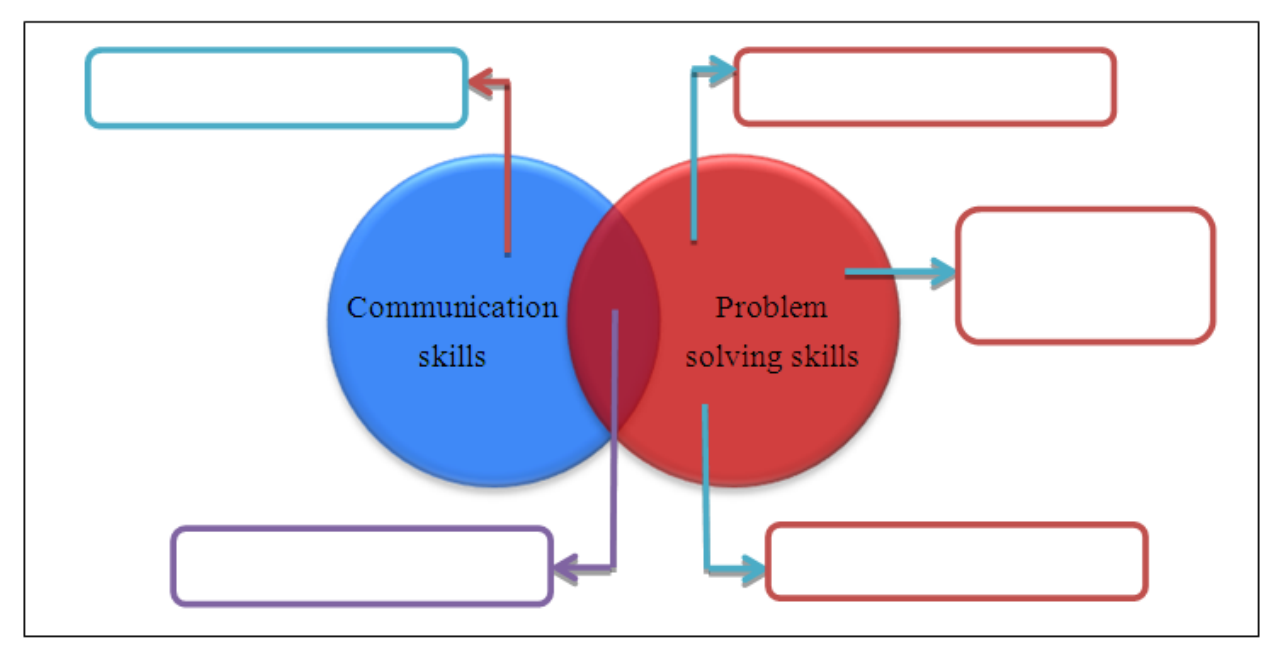

Figure 1. Soft skills' teaching method model (SoSTeM)

Based on Figure 2, there are five methods of effective teaching \& learning in increasing soft skills involving communication skills and problem solving skills. Although seven elements of soft skills were studied, the results showed that only two soft skills element can be applied effectively by lecturers. The use of lectures and project methods by the lecturers during the process of teaching and learning found to be effective in applying communication skills among students. This is in line with the statement by Pineteh (2012) which stated that the effectiveness use of the lecture method is able to attract students, and also can improve students' communication skills. SoSTeM model also shows that project methods suitable for encourage students to apply communication skills and problem solving skills. This model supports the statement by Nachiappan et al. (2009) and Mok (2004) 
which stated that the project methods encourages students to include the cognitive, affective and psychomotor domain and able to display their talents in a real situation.

Researchers conclude that practical methods, demonstration methods, interactive methods and project methods used by the lecturer during the process of teaching and learning were effective in applying problem solving skills to students. This is in line with a study conducted by Buntat et al. (2008) which stated that activities in laboratories and workshops at the polytechnic promote creative and problem-solving skills among students. According to Eggen and Kauchak (2001) in their book, demonstration method can focus students' attention to the process of teaching and learning conducted involving hearing, seeing, and trial and error, while interactive methods encourage students to foster critical and creative thinking, build confidence and encourage the sharing of views and fostering the spirit of cooperation among students as well. The use of a specific teaching \& learning method helps encourage students to apply soft skills and further enhance additional skills possessed by students.

\section{Conclusion}

The application of soft skills among engineering students is one of the important elements in producing quality graduates and meeting the needs of the industry. Soft skills in the process of teaching and learning in engineering program at the polytechnic curriculum will not succeed without the cooperation of lecturers and students. Studies indicate that lecturers need to maintain good relationships with the students so that students will not feel abandoned during the teaching \& learning process. This study also suggests that lecturers should plan more class activities to increase the level of soft skills among students. Thus, it is indirectly helpful to lecturers to improve the application of soft skills among students. This study also found that there are a variety of methods and approaches that can be used in applying the elements of soft skills in the process of teaching and learning engineering programs at the polytechnic. It is hoped that this study can provide an insight into the polytechnic view to develop an appropriate curriculum in improving the soft skills of students in Malaysian polytechnics.

\section{Acknowledgments}

A special gratitude to Universiti Tun Hussien Onn Malaysia and Centre of Research, Innovation, Commercialization \& Consultancy Office (RICC) in aiding this research under the Fundamental Research Grant Scheme (FRGS Vot 1068).

\section{References}

Abu, M. S., Kamsah, M. Z., \& Razzaly, W. (2008). Laporan kajian soal selidik penerapan kemahiran insaniah (KI) di kalangan pelajar dalam aktiviti $P \& P$ di Institut Pengajian Tinggi Awam. Putrajaya: Jawatankuasa Penerapan Kemahiran Insaniah Kebangsaan.

Ahmad-Anuar, A., \& Esa, A. (2010). Penerapan kemahiran insaniah di Pusat Giat Mara (PGM): Satu analisis perbandingan. In A. Esa, \& M. Z. Mustafa (Eds.), Kemahiran insaniah: kajian di Institusi-institusi Pengajian Tinggi (pp. 1-19). Batu Pahat: Penerbit UTHM.

Alexander, R. (2008). Pedagogy, curriculum and culture. In K. Hall, P. Murphy, \& J. Soler (Eds.), Pedagogy and practice: Culture and identities (pp. 3-27). London: Sage Publications Ltd.

Buntat, Y., Saud, M. S., \& Hussain, H. A. (2008). Cabaran Politeknik Sultan Ahmad Shah (POLISAS) membangunkan modal insan sejajar dengan keperluan sektor industri. 3rd International Conference on Education 2008.

Che-Ani, A. I., Tawil, N. M., Johar, S., Ismail, K., \& Abd-Razak, M. Z. (2014). Universiti Kebangsaan Malaysia Learning Contract Course: Experience and Performance of the First Cohort. International Education Studies, 7(2), 1-9. http://dx.doi.org/10.5539/ies.v7n2p1

Curtis, D. D. (2004). International perspectives on generic skills. In J. Gibbs (Ed.), Generic skills in vocational education and training: research readings (pp. 19-37). Adelaide: NCVER Ltd.

Eggen, P. D., \& Kauchak, D. P. (2001). Strategies for teacher: Teaching content and thinking skills. New York: Allyn and Bacon.

Hamzah, R., Bakar, A. R., \& Kazilan, F. (2006). Pengintegrasian kemahiran employability dalam pembelajaran: Pandangan pengajar pusat latihan teknikal dan vokasional di Malaysia. Prosiding seminar kebangsaan teknik dan vokasional (pp. 278-283). Skudai: Penerbit UTM.

Hashim, S., Yaakub, R., \& Ahmad, M. Z. (2003). Pedagogi: Strategi dan teknik mengajar dengan berkesan. Bentong: PTS Publication \& Distributor Sdn. Bhd.

Kapsos, S. (2013). Global Employment Trends for Youth. Retrieved from 
http://www.ilo.org/public/libdoc/igo/2013/481543.pdf

Knight, J. A., \& Elliot, J. F. (2008). TVET teaching education: A vision beyond tradition. Journal of Technical and Education Training, 1, 73-83. Retrieved from http://penerbit.uthm.edu.my/ojs/index.php/JTET/article/ view/284/164

Koprowska, J. (2006). Communication and interpersonal skills in social work. Exeter: Learning Matters Ltd.

McIntosh, S. (2008). Education and employment in OECD countries. Paris: United Nations Educational, Scientific and Cultural Organization.

Ministry Of Higher Education. (2006). Modul pembangunan kemahiran insaniah (soft skills) untuk Instutusi Pengajian Tinggi Malaysia. Serdang: Penerbit Universiti Putra Malaysia.

Mohd-Amin, N. F., \& Mohd-Nor, S. (2010). Tinjauan terhadap guru di Sekolah Menengah Teknik Negeri Johor terhadap penerapan kemahiran generik dalam proses pengajaran dan pembelajaran mata pelajaran kejuruteraan (pp. 1-8). Retrieved from http://eprints.utm.my/11167/

Mok, S. S. (2004). Pedagogi untuk kursus diploma perguruan semester 3. Petaling Jaya: Kumpulan Budiman Sdn. Bhd.

Morris, A. (2009). The stretched academy: The learning experience of mature students from under-represented groups. In L. Bell, H. Stevenson, \& M. Neary (Eds.), The future of higher education (pp. 99-111). New York: Continuum International Publishing Group.

Nachiappan, S., Kamaruddin, K., Abd-Shukor, A. A., Jantan, R., Mustapha, R., \& Hamzah. (2009). Pembelajaran dan perkembangan pelajar. Shah Alam: Oxford Fajar Sdn. Bhd.

Neary, M., \& Winn, J. (2009). The student as producer: Reinventing the student experience in higher education. In L. Bell, H. Stevenson, \& M. Neary (Eds.), The future of higher education (pp. 126-138). New York: Continuum International Publishing Group.

Ormrod, J. E. (2006). Educational Psychology: Developing Learner. New Jersey: Pearson Education Inc.

Pineteh, E. A. (2012). Using virtual interactions to enhance the teaching of communication skills to information technology students. British Journal of Educational Technology, 43(1), 85-96. http://dx.doi.org/10.1111/j.1467-8535.2011.01193.x

Redoli, J., Mompo, R., Mata, D. D. L., \& Doctor, M. (2011). DLP: A tool to develop technical \& soft skills in engineering. Computer Applications in Engineering Education, 21(1), E51-E61. http://dx.doi.org/10.1002/cae.20572

Wye, C. K., \& Lim, Y. M. (2009). Perception Differential between Employers \& Undergraduates on The Important of Employability Skills. International Education Studies, 2(1), 95-105. http://dx.doi.org/10.5539/ies.v2n1p95

Zainal-Abidin, D. (2004). 7 formula individu cemerlang. Bentong: PTS Publication \& Distributors Sdn. Bhd.

Zepke, N., \& Leach, L. (2010). Beyond hard outcomes: 'soft' outcomes and engagement as student success. Teaching in Higher Education, 15(6), 661-673. http://dx.doi.org/10.1080/13562517.2010.522084 


\section{Appendix}

Figure A1. Teaching \& learning methods for improving soft skills

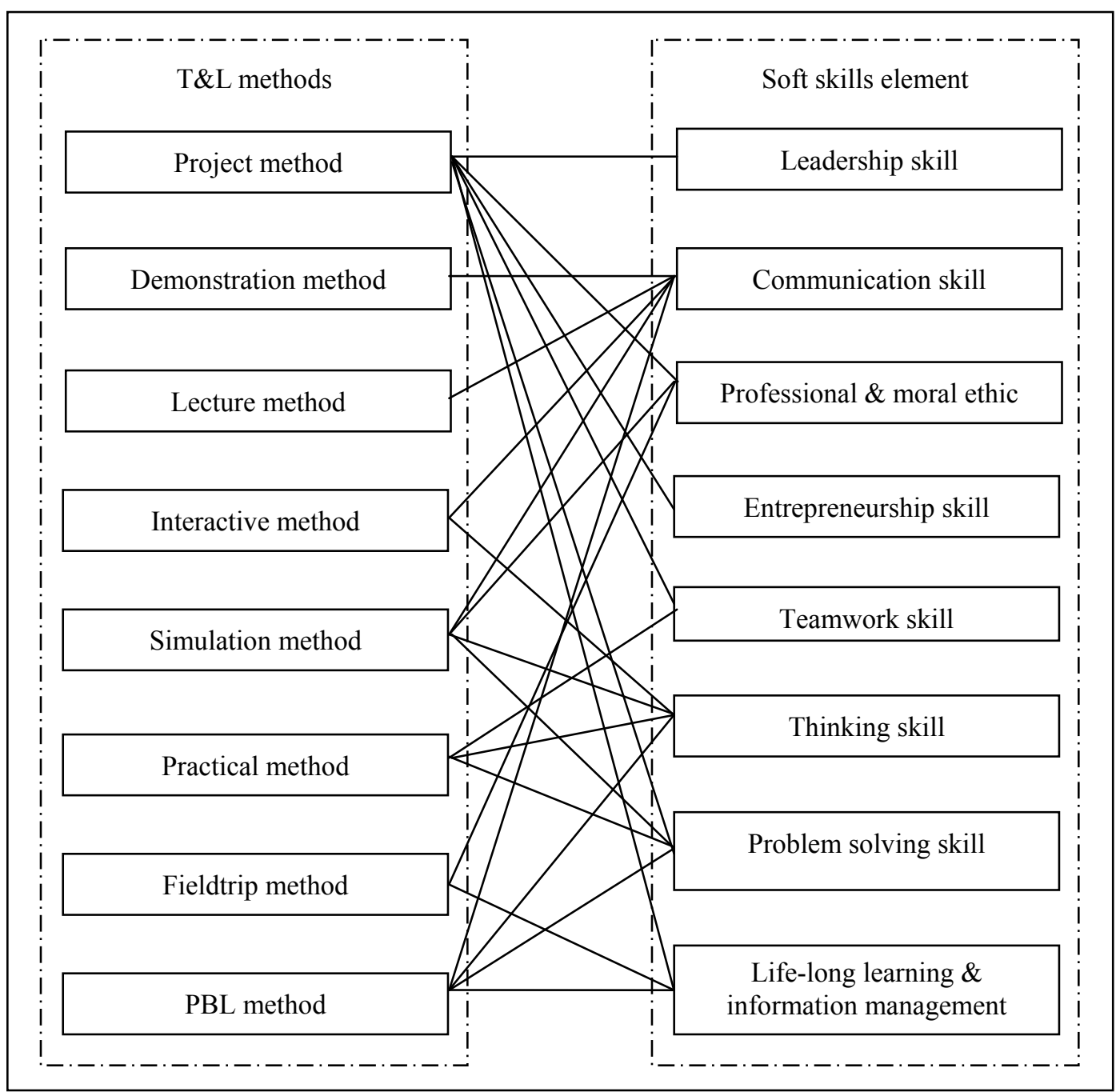

\section{Copyrights}

Copyright for this article is retained by the author(s), with first publication rights granted to the journal.

This is an open-access article distributed under the terms and conditions of the Creative Commons Attribution license (http://creativecommons.org/licenses/by/3.0/). 